\title{
La rugosité dans les modèles à fond fixe fortement distordus
}

\author{
Resistance in strongly distorted fixed bed models
}

Chacun sait que dans un modile distordu la pente excessive de la ligne dean doil itre compensée par un accroissement de la rugosité. La plupart du temps ce résultat est oblenu par une exageration de la rugosite des parois. La loi de similitude, exigeant que tous les termes de léquation dynamique soient réduits dans la mine proportion, permet de trouver le cocficient d'augmentation nécessaire.

Dapres lépuation :

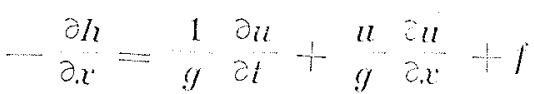

le terme de frotlement f derrat ètre róduil dans la mème proportion que la pente de la ligne d'eau, autrement dit suivant le rapport $n_{*}: n_{h}$ $\left(n_{i}=\mathrm{H}: h\right.$ étant l'échelle verticale, $n_{n}=\mathbf{L}$ : $l$ ćtant échelle horizontale). Dans les rivieres et les chenaux soumis à la marée qui, en général, constituent lobjet des modiles en cause, les écoulements turbulents rencontrés sont du type « rugueux ». I.e frottement, dans ce cas, est proportionnel au carré de la vitesse, of le coefficient de frottement dépend surtout du rapport entre la rugosite du lit K et le rayon hydraulique $R$ (dans les riviores et chenaux de grande largeur, leffet des frottements latéraux est négligeable et la part de la résistance tolale due aux irrégularités du cours et de la section transversale, telle que les méandres et les modifications du profil, n'ont pas une influence fondamentale dans le problème éludió).

Nous avons ainsi :

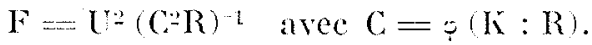

It is common knowledge that, in a distorted model, the steep slope of the water surface has to be counterbalanced by an increased resistance. In many cases, this is obtained by exaggerating the roughness of the bed. The law of similarity, requiring that all terms in the dynamic equation be subject to the same scale ratio, enables the necessary exaggeration to be found.

From :

$$
\frac{\partial h}{\partial x}=\frac{l}{g} \frac{\partial u}{\partial t}+\frac{u}{g} \frac{\partial u}{\partial x}=f
$$

it follows that the friction-term of should be reduced in the same ratio as the slope of the surface, i.e. with $n_{v}: n_{h}\left(n_{v}=\mathrm{H}: h\right.$ being the vertical, $n_{h}=\mathrm{L}: l$ being the horizontal scale).

The objects of the models dealt with here are generally rivers and tidal channels, in which turbulent flow of the "rough » type is found. The friction in this case is proportional to the square of the velocity of flow and the friction coefficient depends chiefly on the ratio of the bed roughness $K$ to the hydraulic radius $R$ (in wide rivers and channels, the effect of the side friction is negligible and that part of the total resistance which is due to irregularities in the course and the cross-section, such as bends and changes in profile, is not essential to the problem dealt with).

Thus we have:

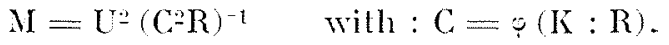




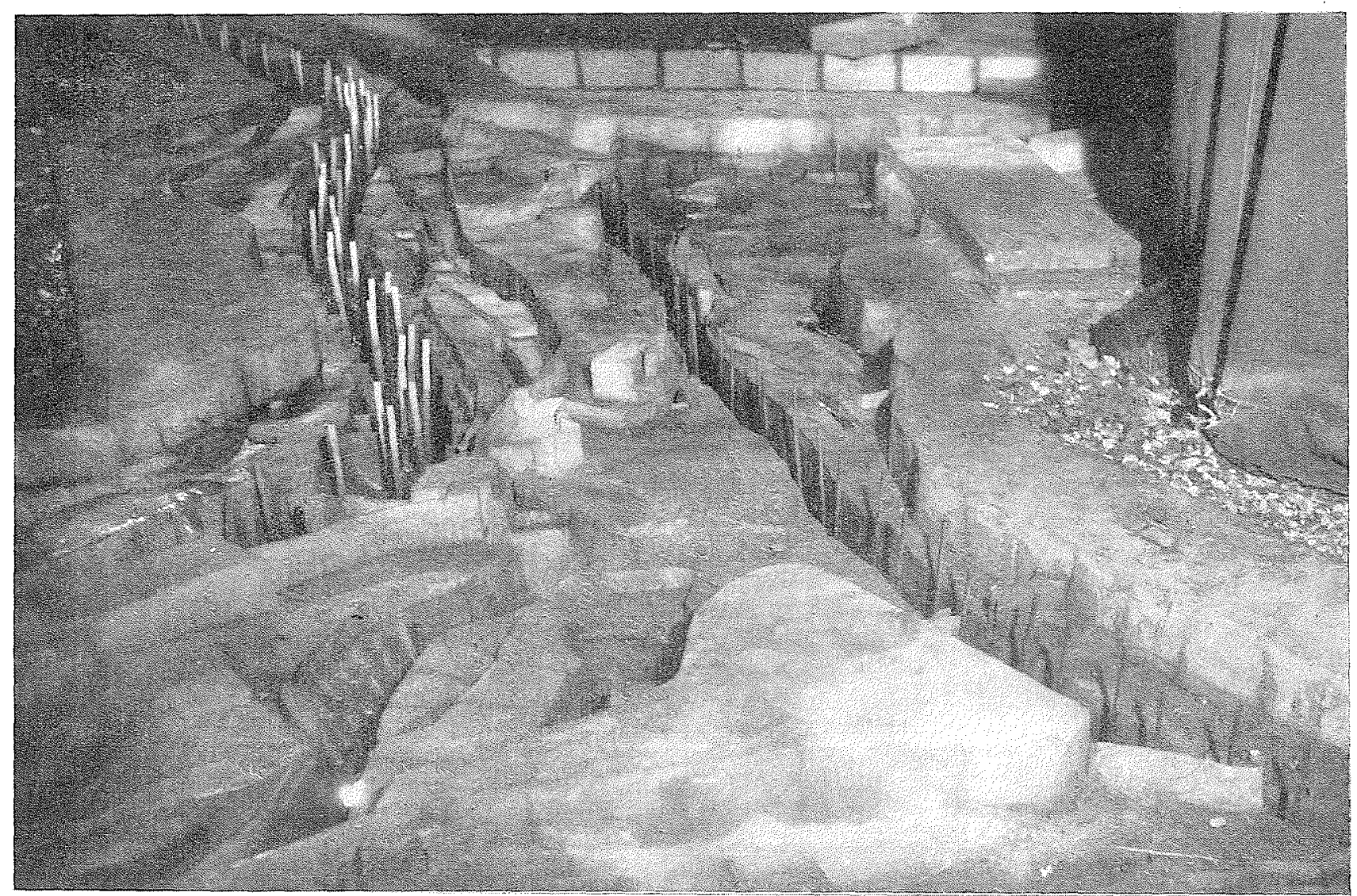

En admettant que l'écoulement sur le modèle soit du même type que celui de la nature, nous avons aussi :

$$
f=u^{2}\left(c^{2} r^{r}\right)^{-1} \text { avec } c=\varphi\left(k: r^{\prime}\right)
$$

et puisque, comme nous avons vu $n_{f}=n_{v}: n_{u}$, nous trouvons :

$$
n_{c}=\frac{n_{h^{2}} n_{u}}{n_{v^{2}}^{2} n_{r}}
$$

Dans beaucoup de modèles distordus (c'est le cas des modèles à marée), l'échelle des vitesses $n_{u}$ doit être prise égale à la racine carrée de l'échelle verticale $\left(n_{l l}=n_{v} \frac{1}{2}\right)$. Dans ce cas, l'expression (2) se simplifie et devient :

$$
\left.n_{c}=\left(n_{h}: n_{r}\right)\right)_{2}
$$

Tandis que, dans la nature, la grande largeur des rivières et des chenaux permet généralement de remplacer le rayon hydraulique $\mathbf{R}$ par la profondeur moyenne $\mathrm{D}$, ceci n'est que très rarement possible sur le modèle. Dans un tel cas, au lieu de l'expression $\left(2^{\prime}\right)$, nous pouvons écrire :

$$
n_{e}=\left(n_{h}: n_{v}\right) \text { 弪 }
$$

Providing that the flow in the model has the same character as in nature, we also have :

$$
f=u^{2}\left(c^{2} r\right)^{-1} \quad \text { with }: c=\varphi\left(k: r^{r}\right),
$$

and since, as we have seen, $n_{f}=n_{v}: n_{k}$, we find:

$$
n_{c}=\frac{n_{l}: 2 n_{u}}{n_{v}: n_{r}}
$$

In many distorted models (e.g. tidal models), the velocity scale $n_{u}$ has to be taken as the square root of the vertical scale $\left(n_{n}=n_{v} \frac{1}{2}\right)$, in which case the expression (2) is simplified into :

$$
n_{\varepsilon}=\left(n_{k}: n_{r}\right) ?
$$

Whereas in nature the great width of the rivers and channels generally allows the hydraulic radius $R$ to be replaced by the mean depth $\mathrm{D}$, this is only possible on the model in rare cases. In these cases instead of $\left(2^{\prime}\right)$ we may write :

$$
n_{c}=\left(n_{l}: n_{v}\right)^{\frac{1}{2}}
$$


Dans la majorité des cas, cependant, $n$, prend une valeur comprise entre $n_{v}$ et $n_{h}$. La différence entre $n_{r}$ et $n_{v}$ est d'autant plus grande que le chenal est plus étroit.

Il résulte des formules (2') et (2") que, sur un modèle fortement distordu, le coefficient de Chezy devrait ètre beaucoup plus petit que dans la nature, autrement dit la rugosité relative du lit sur le modèle devrait dépasser de loin la rugosité naturelle.

L'expérience montre quil ne suffit pas toujours de rendre le chenal rugueux : c'est le cas par exemple lorsque les aspérités devraient avoir des dimensions plus grandes que le rayon hydraulique.

C'était en particulier le cas du modèle représentant le Rhin et la Meuse dans leur partie soumise à la marée; modèle qui est actuellement en exploitation au Laboratoire d'Hydraulique de Delft (les échelles en sont pour les longueurs $n_{h}=2.400$ et pour les hautèurs $n_{v}=64$ ).

On fut donc amené à adopter une autre méthode pour obtenir sur le modèle une résistance suffisante. Cette méthode consistait à placer dans le modele un grand nombre de petites « chicanes ». Dans le cas particulier, celles-ci étaient réalisées soit par des tiges verticales en cuivre de section carrée $(1 / 2 \mathrm{~cm}$ de côté), soit par des lames de zinc larges de 1 ou $2 \mathrm{~cm}$ scellées dans le ciment. Les photographies ci-jointes montrent ces deux types de chicanes.

Pour un tronçon de rivière, sur le modèle, la résistance totale peut être considérée comme la résultante des frottements sur le lit d'une part, et de la somme des frottements dues aux chicanes d'autre part. La perte de charge dans un troncon de rivière de longueur $l$ s'exprime donc par :

$$
l f=\frac{l u^{2}}{c^{2} r}+\frac{\Sigma b}{\rho g a}
$$

où $b$ représente la résistance d'une chicane isolée et a la section mouillée.

\section{English text}

$0.5 \mathrm{sq}$. cm. and thin zinc strips, 1 to $2 \mathrm{~cm}$ in width, fixed to the bed by means of cementmortar. The photos show both types of baffles.

The resistance in a stretch of river in the model can be considered to be composed of bed friction on one hand and of the sum of the resistance of the baffles on the other. For the loss of head in a stretch of river of length $l$, this leads to :

$$
l f=\frac{l u^{2}}{c^{2} r^{2}}+\frac{\Sigma b}{\rho g a}
$$

where $b$ represents the resistance of a single baffle, and $a$ the cross-sectional area.
In the majority of cases, however, $n_{r}$ has a value somewhere between $n_{v}$ and $n_{k}$. The narrower the channel, the greater is the difference between $n_{r}$ and $n_{v}$.

It follows from formulae (2') and $\left(2^{\prime \prime}\right)$ that in a channel of a strongly distorted model, the Chézy coefficient should be much smaller than in the corresponding channel in nature, that is to say, the relative bed roughness should far exceed that of the natural channel.

Experience shows that, in practical cases, a roughening of the channel is not always sufficient, since for instance, a measure of unevenness may be required which exceeds the hydraulic radius. Such was the case on the model of the tidal region of the rivers Rhine and Meuse, which is, at present, in operation at the Delft hydraulic laboratory (scales $n_{h}=2400$, and $n_{v}$ $=64$ ). Another method of obtaining sufficient resistance on the model was therefore applied, i.e., the inclusion of numerous small baffles. In this case, they consist of vertical brass rods of (Suite, col. 1.)

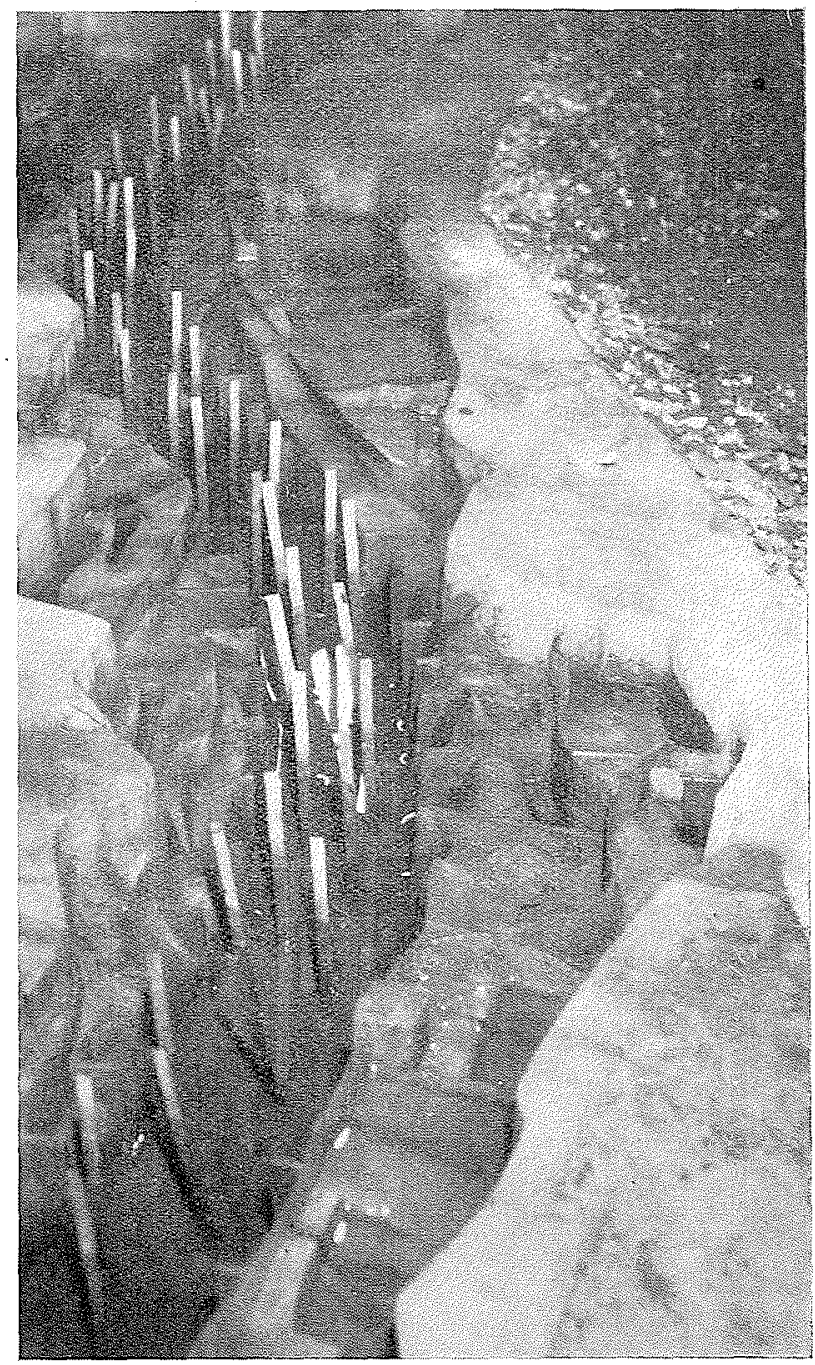




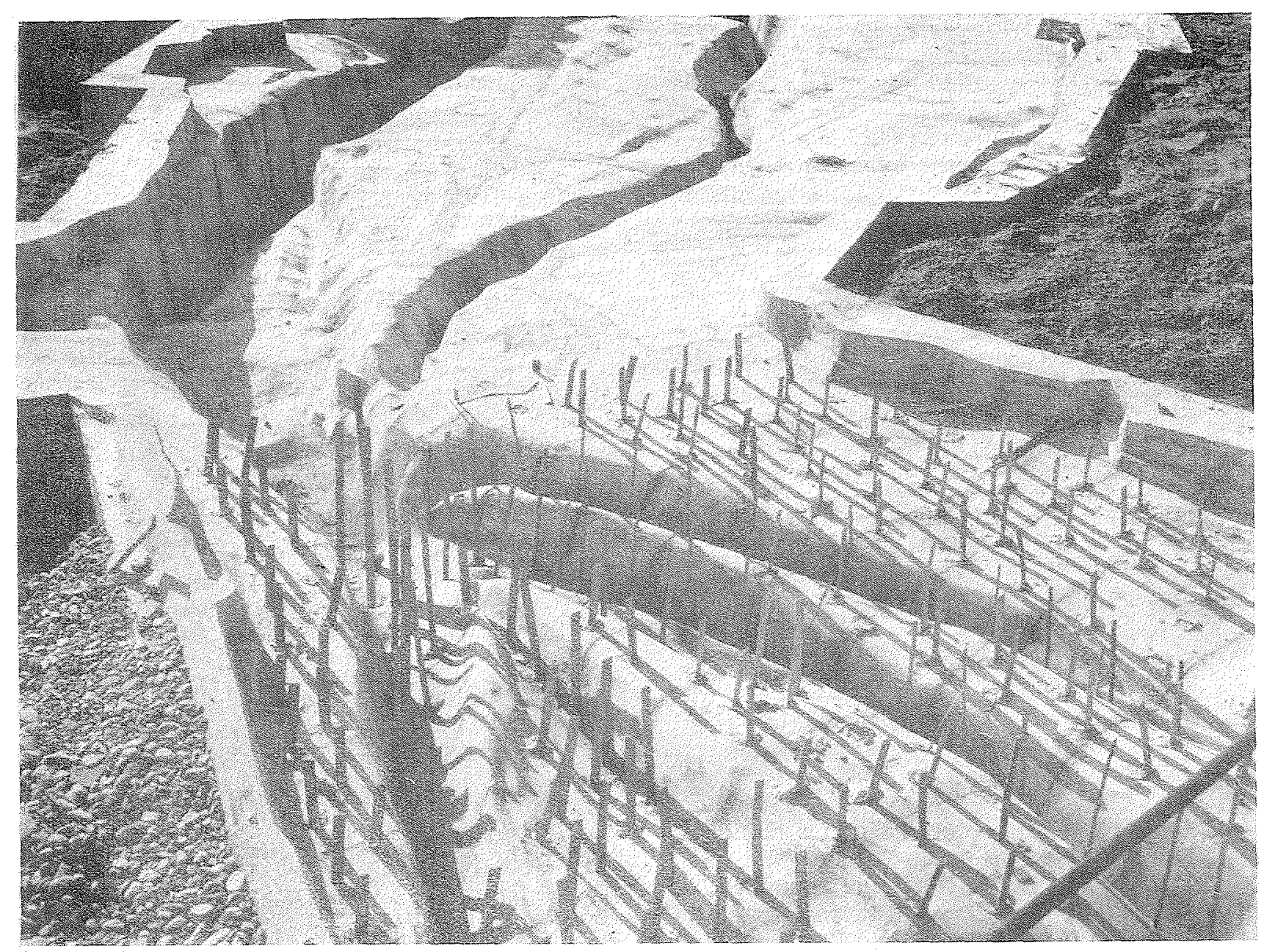

Dans un icoulement turbulent completement développé, b est également proportionnel au carré de la vilesse. On peut done excre:

$$
b=\operatorname{shlb} \frac{1}{2}, n^{2}
$$

où ミ est un coefficient ot $h$ et $b$ respectivement ta hatuteur el la largeur des chicanes.

Si dans un troncon de longueur $l$ les chicanes sont toutes identiques et sont disposées de telle facon que chacune puisse etre affectée du mème coefficient, la condition de similitude sécrit :

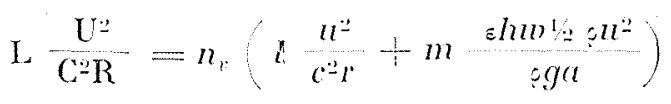

oll puisque :

$$
\begin{gathered}
n_{\mathrm{u}}{ }^{2}=n_{v} \\
\frac{1}{\mathrm{C}-\mathrm{R}}=\frac{1}{n_{h}}\left(\frac{1}{c^{2}-1}+m \frac{s h w}{2 g a l}\right)
\end{gathered}
$$

In fully developed turbulent flow, $b$ is also proportional to the square of the velocity of flow Hence we can wite:

$$
b=5 h u 1 / 2 \div u^{\prime}
$$

where $\varepsilon$ is a coeflicient, and $h$ and $b$ are the height and widh of the bafle respectively.

If, in a stretch of length $l$, the baflles are identical and so placed that one can allow cach to have an equal coefficient, the condition of similarily is :

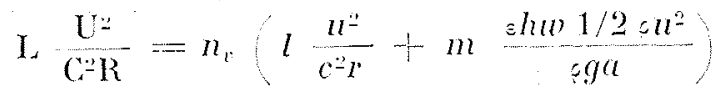

() I, as $n_{u}{ }^{2}=n_{v}$ :

$$
\frac{l}{C^{-2} \mathrm{R}}=\frac{l}{n_{h}}\left(\frac{l}{c^{2} r}+m \frac{s h w}{2 g a l}\right)
$$


Le nombre $m$ des chicanes devant ète mises en place dans ce troncon peut ètre calculć d'apris les expressions ci-dessus, une fois e el a délerminés par des mesures portant sur la rugosilé et sur la résistance done seule ehicane fou bien celle din groupe de chicanes disposées selon une mélhode donnce).

Dans le cas des modiles de Dellt, semle la mesure de la résistance dune chicane bat néeessaire, la rugosite du lit en ciment étant déjà connue grâce ì des recherches antéricures sur des surfaces du meme type. Dapres des essais de contròle réalisés sur le modile ainsi équipé, il s'avere que dans chacun des troneons de la riviere el de l'estuaire la valeur atteinte pour le coefficient $\mathrm{C}$ ćlait, à quelques \% pris, colle que l'on s'était fixé : une telle précision dipasse celle que lion obtiont pour la determination de C dans la nature. It est d'alleurs extrememont facile, si nécessaire, de proceder à des corrections en ajoutant ou en retianchant quelques chicanes.

Nous derons maintenant attirer l'attention sur les conditions particulieres qui se trouvent rea-
The required number $m$ of the baflles to be put in this stretch can be calculated from the above after determination of $c$ and $s$ by measurements of the bed roughness of the model and of the resistance of a single baflle (or of a group of bafles arranged in a certain patlerny.

In the case of the Delft model, it was only necessary to measure the bafle resistance, as the roughness of the cement bed was already known from earlier experiments with the same type of surface.

From check lests on the completed model it appeared that, in every separale streteh of river and tidal chamnel, the $C$ value ammed al was achiered wilhin a few percent, an accuracy excoeding that obtained when determining " $C$ in nature. If necessary, howerer, a correction is very easily made by either removing or adding baffles.

Attention should be drawn to a point that oceurs concerning channels where the tidal am-

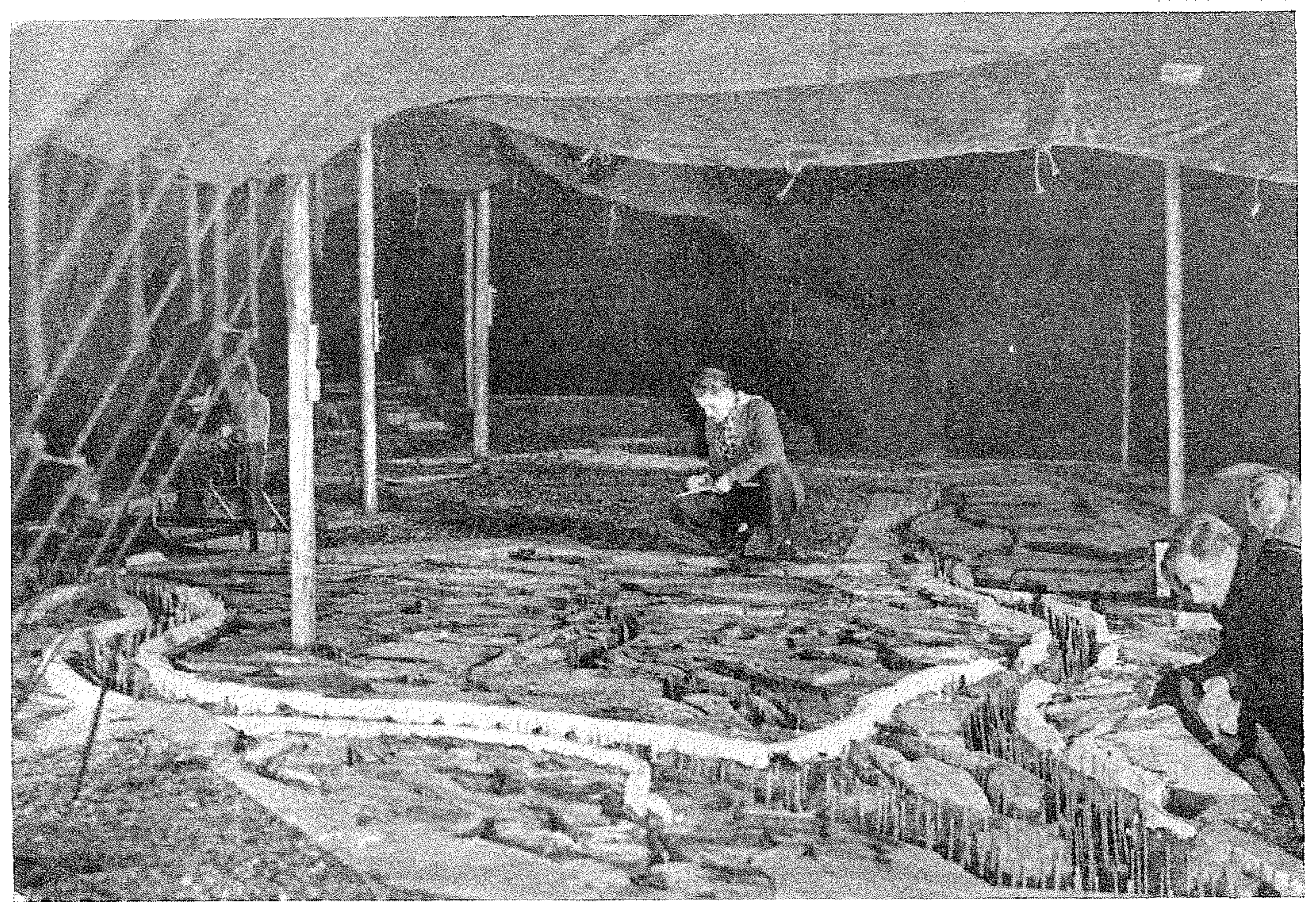


lisées lorsque l'amplitude de la marée a une valeur importante par rapport à la profondeur d'eau : il en résulte en effet une très sensible variation de $R$ au cours du déroulement de la marée.

Dans la nature, $R$ varie pratiquement comme la profondeur moyenne; si bien que $\left(\mathrm{C}^{2} \mathrm{R}\right)^{-1}$ est inversement proportionnel à celle-ci. Le deuxieme terme de l'expression de droite de l'équation (5) devrait se comporter de la même façon. Ceci peut être obtenu en adoptont des chicanes constamment submergées : la valeur de $h$ est alors constante.

Etant donné que, dans un modèle fortement distordu, la section transversale a est, elle aussi, pratiquement proportionnelle à la profondeur moyenne à chaque instant, le terme $m \frac{\varepsilon h w}{2 g a l}$ est inversement proportionnel à cette profondeur moyenne. Bien que ceci ne s'applique pas à $\left(c^{2} r^{2}\right)^{-1}$, ce terme est généralement sans grande importance (sur le modèle de Delft il dépasse rarement $1 / 10$ de la résistance totale).

Lors de la réalisation du modèle de Delft, seules les conditions de niveau moyen furent prises en considération, et ce derniex point fut négligé. Bien que, sur certains troncons, un tel effet aurait pu être nettement mesurable en accord avec le calcul, on n'a décelé aucune diflérence appréciable dans le déroulement des phénomènes : ceci n'a pas pour l'instant recu d'explication satisfaisante.

Dans le cas de hauteurs d'eau très faibles, ou lorsque l'on se trouve sur des hauts fonds, il est évidemment impossible de maintenir en permanence les chicanes en dessous des basses eaux. Il faut alors se résigner à opérer avec des résistances qui ne sont vraiment correctes que pour une hauteur d'eau déterminée. plitude is important compared with the depth of water, this causing an important variation of $\mathrm{R}$ during the tidal cycle. In the natural channel, $R$ varies practically proportionally to the mean depth and the variation of $\left(C^{2} R\right)^{-1}$ is therefore inversely proportional to it. The second term on the right hand side of equation (5) should behave in the same way. This can be achieved by using baffles which remain submerged all the time, making $h$ a constant value. As in a strongly distorted model channel, the crosssectional area is also practically proportional to the mean depth at each instant; the term :

$$
m \frac{\varepsilon h w}{2 g a l}
$$

varies inversely proportionally to that depth. Though this does not apply to $\left(c^{2} r\right)^{-1}$, this term is usually rather unimportant (in the Delft model it rarely exceeds one tenth of the total resistance).

When the model was constructed in Delft, attention was given only to conditions at mean water levels and this point has been over-looked. Though in some of the channels the effect of this should clearly be measurable according to computation, no appreciable difference in behaviour has been found, a fact which, up to now, has not been satisfactorily explained.

In very shallow channels and on shoals it is obviously not possible to keep the baffles below low water. The fact that the resistance cannot be correct at every stage of the tide has to be accepted in this case.

Delft, November 1949 .

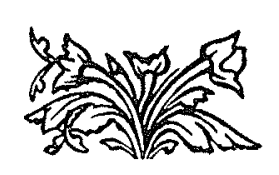

